\title{
Left Spermatic Artery
}

National Cancer Institute

\section{Source}

National Cancer Institute. Left Spermatic Artery. NCI Thesaurus. Code C52739.

An artery arising from the abdominal aorta, below the renal artery, that supplies the left testicle. 